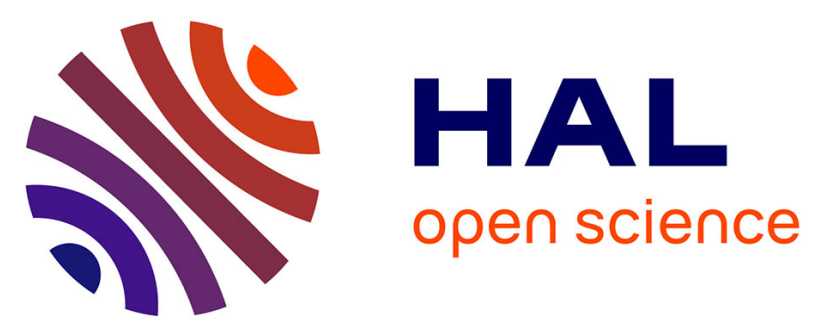

\title{
Osmoregulatory responses to cadmium in reference and historically metal contaminated Gammarus fossarum (Crustacea, Amphipoda) populations
}

Paul Dayras, Guy Charmantier, Arnaud Chaumot, Amandine Vigneron, Marina Coquery, Herve Queau, Ester Artells, Jehan-Herve Lignot, Olivier Geffard, Julien Issartel

\section{To cite this version:}

Paul Dayras, Guy Charmantier, Arnaud Chaumot, Amandine Vigneron, Marina Coquery, et al.. Osmoregulatory responses to cadmium in reference and historically metal contaminated Gammarus fossarum (Crustacea, Amphipoda) populations. Chemosphere, 2017, 180, pp.412-422. 10.1016/j.chemosphere.2017.04.016 . hal-01681622

\section{HAL Id: hal-01681622 https://hal.science/hal-01681622}

Submitted on 15 May 2018

HAL is a multi-disciplinary open access archive for the deposit and dissemination of scientific research documents, whether they are published or not. The documents may come from teaching and research institutions in France or abroad, or from public or private research centers.
L'archive ouverte pluridisciplinaire HAL, est destinée au dépôt et à la diffusion de documents scientifiques de niveau recherche, publiés ou non, émanant des établissements d'enseignement et de recherche français ou étrangers, des laboratoires publics ou privés. 


\title{
Osmoregulatory responses to cadmium in reference and historically metal contaminated Gammarus fossarum (Crustacea, Amphipoda) populations
}

\author{
Paul Dayras ${ }^{\mathrm{a}, \mathrm{c}}$, Guy Charmantier ${ }^{\mathrm{a}}$, Arnaud Chaumot ${ }^{\mathrm{b}}$, Amandine Vigneron ${ }^{\mathrm{b}}$, \\ Marina Coquery ${ }^{\mathrm{b}}$, Hervé Quéau ${ }^{\mathrm{b}}$, Ester Artells ${ }^{\mathrm{c}}$, Jehan-Hervé Lignot ${ }^{\mathrm{a}}$, Olivier Geffard ${ }^{\mathrm{b}}$, \\ Julien Issartel ${ }^{\mathrm{c}, *}$ \\ a UMR 9190, Université de Montpellier, 34095 cx 05, Montpellier, France \\ ${ }^{\mathrm{b}}$ Irstea, UR MALY, Centre de Lyon-Villeurbanne, F-69616, Villeurbanne, France \\ ${ }^{c}$ Aix Marseille Univ, Avignon Univ, CNRS, IRD, Institut Méditerranéen de Biodiversité et d'Ecologie marine et continentale (IMBE), 3 place Victor Hugo, \\ 13331 cx 03, Marseille / Europôle de l'Arbois, Aix-en-Provence, France
}

\section{H I G H L I G H T S}

- Osmoregulatory responses to Cd were studied in 3 Gammarus populations.

- One population lives in a Cd-contaminated river, the others inhabit $\mathrm{Cd}$-free sites.

- High inter-individual variations in osmoregulation were noted in 2 populations.

- Gills of Cd-impacted animals showed histopathology, ion transporters overexpression.

- No obvious correlation was found between osmoregulatory responses and sampling sites.

Keywords:

Crustacean

Cadmium

$\mathrm{Na}^{+} / \mathrm{K}^{+}$-ATPase

$\mathrm{V}-\mathrm{H}^{+}$-ATPase

Histology

Immunolocalization

\begin{abstract}
A B S T R A C T
In order to better understand the variable sensitivities of crustaceans to metals, we investigated the impact of cadmium exposure in 3 populations of Gammarus fossarum from different rivers of France. The first population lives in a Cd-contaminated river from a geochemical background, while the others inhabit Cd-free sites. Osmoregulation, a relevant biomarker to evaluate crustacean health following metal contamination, was used as a proxy to evaluate the intra- and inter-populationnal sensitivities to $\mathrm{Cd}$. Specimens from each population were experimentally exposed to $9 \mu \mathrm{g} \mathrm{Cd}{ }^{2+} / \mathrm{L} \mathrm{Cd}$ for 7 days and hemolymph osmolality (HO) was then individually measured. In exposed populations, high interindividual variations in $\mathrm{HO}$ values were noted, resulting in their separation into non-impacted and slightly or highly Cd-impacted (with lower HO) animals. In gills of impacted organisms, deep histopathological alterations and protein overexpression of $\mathrm{Na}^{+} / \mathrm{K}^{+}$-ATPase and $\mathrm{V}-\mathrm{H}^{+}$-ATPase were observed through histology and immunolocalization, while non-impacted animals showed profiles comparable to controls. Moreover, the osmoregulatory processes in the population living in the Cd-contaminated site were impacted by acute $\mathrm{Cd}$ exposure in the laboratory as much as for one of the two populations originating from $\mathrm{Cd}$-free sites. The observed changes did not reveal any obvious adaptive osmoregulatory phenomena at the population scale, but they may be due to differences in fitness between individuals and between populations in relation to the features of their respective environments, unrelated with the presence of the metal.
\end{abstract}

Abbreviations: HO, hemolymph osmolality; NKA, $\mathrm{Na}^{+} / \mathrm{K}^{+}$-ATPase; VHA, V-H ${ }^{+}$-ATPase; NI, non-impacted; SI, slightly impacted; HI, highly impacted; Ard, Ardillats; TdP, Tour du Pin; Bas, Bastide.

* Corresponding author.

E-mail address: julien.issartel@imbe.fr (J. Issartel).

\section{Introduction}

The aquatic environment is subjected to increasing contamination by metals that, in addition to geochemical backgrounds, is mainly due to past and present mining activities and to the 
continuous industrialization of watersheds since the industrial revolution. In France, some cadmium-contaminated streams show mean annual concentrations of up to $22 \mu \mathrm{g} / \mathrm{L}$ (e.g. Riou Mort, France; Morin et al., 2008). In crustaceans, water-borne cadmium is known to induce a decline of the overall performance in feeding rate, locomotor and ventilation activities, metabolic rate and mating (Lawrence and Poulter, 1998; Maltby et al., 2002; Wallace and Estephan, 2004; Wu and Chen, 2005; Mills et al., 2006). Cadmium is also known to severely impact osmoregulation in crustaceans (review in Charmantier et al., 2009) and among them in amphipods (Felten et al., 2008; Issartel et al., 2010). Osmoregulation is a vital physiological mechanism conditioning the maintenance of the overall metabolism and plays a major role in the distribution of aquatic organisms. In freshwater crustaceans, body fluids are strongly regulated hyperosmotic to the external environment, thus against water invasion and ion loss. Compensatory active uptake of ions from the water is performed through the gills into body fluids. Ion transport is performed by specific transmembrane enzymes and ion channels, highly expressed in specific cells of the gill epithelium, the ionocytes. Two major ionocyte enzymes involved in osmoregulation play a key role in ion uptake: the basolaterally located $\mathrm{Na}^{+} / \mathrm{K}^{+}$-ATPase (NKA) and, particularly in fresh water, the apically located $\mathrm{V}-\mathrm{H}^{+}$-ATPase (VHA) (review in Charmantier et al., 2009; McNamara and Faria, 2012).

The freshwater amphipod crustacean Gammarus fossarum (Koch, 1836) is commonly found in West Paleartica streams (Karaman and Pinkster, 1977). Previous studies have revealed that G. fossarum sampled from a reference population (River Bourbre, France) and exposed to $15 \mu \mathrm{g} \mathrm{Cd} / \mathrm{L}$ for 3 and 7 days showed a decrease in hemolymph osmolality (Felten et al., 2008; Issartel et al., 2010), resulting from a strong alteration of the gill tissues (collapse of the gill epithelium resulting in the disappearance of the hemolymph canals, hyperplasia), along with a disturbed expression of NKA (Issartel et al., 2010). Interestingly, though exposed groups showed significant differences with controls, a high interindividual variability was noted in response to $\mathrm{Cd}$ exposure, with different levels of impact at the sub-individual scale suggesting the existence of a high inter-individual sensitivity to $\mathrm{Cd}$.

In the case study of $\mathrm{Cd}$ impact in Gammarus fossarum, we identified one population (Ardillats: Ard) that reproduces and spends its entire life cycle in a French stream chronically exposed to $\mathrm{Cd}$ due to a geochemical background and low water hardness (Vigneron et al., 2015). Taking this opportunity to further assess the response of crustacean populations to Cd environmental contamination, the present study aimed at investigating the different sensitivities to sub-lethal Cd stress in populations of the amphipod G. fossarum, and explore the importance of pre-exposure of populations in the field using osmoregulation, which allows to accurately determine the physiological status of contaminated organisms at the individual scale. For this, we investigated the osmoregulatory responses to a sub-lethal $\mathrm{Cd}$ exposure in individuals sampled from three populations of Gammarus fossarum of southeastern France: first the population (Ard) identified as chronically exposed to $\mathrm{Cd}$ due to geochemical background (Vigneron et al., 2015); and secondly two populations inhabiting Cd-free sites, one in the River Bourbre flowing in a weakly and sporadically cultivated area (station called Tour du Pin: TdP) which is the population used in our previous studies (Felten et al., 2008; Issartel et al., 2010), and one in a brook spring in a pristine environment (Bastide: Bas). After sampling in the field, all animals were exposed in the laboratory in their river water to $\mathrm{Cd}$ concentrations yielding to $9 \mu \mathrm{g} \mathrm{Cd}^{2+} / \mathrm{L}$ for 7 days. Hemolymph osmolality measurements, histological observations of the gills, and immunolocalization of NKA and VHA were performed as a proxy to highlight potential difference in sensitivities to $\mathrm{Cd}$.

\section{Material and methods}

\subsection{Description of the sampling sites}

Adult gammarids were collected from three different sites. The first population, denoted Ardillats (Ard), is located within an upstream location of the River Ardières, Rhône, France $\left(46^{\circ} 11^{\prime} 11^{\prime \prime} \mathrm{N}\right.$; $\left.04^{\circ} 31^{\prime} 14^{\prime \prime} \mathrm{E}\right)$. This site is characterized by a bioavailable $\mathrm{Cd}$ source coming from a natural geochemical source (Vigneron et al., 2015), ensuring that the Ard organisms have been long-term exposed to $\mathrm{Cd}$. As already used in our previous studies on osmoregulatory disruption by Cd in Gammarus (Felten et al., 2008; Issartel et al., 2010), adult gammarids from the Tour du Pin (TdP) were collected within an upstream location of the River Bourbre, Isère, France $\left(45^{\circ} 34^{\prime} 10^{\prime \prime} \mathrm{N} ; 05^{\circ} 27^{\prime} 34^{\prime \prime} \mathrm{E}\right)$. Gammarids from a third population, called Bastide (Bas), were collected within a brook spring, upstream of a tributary of the Amous River, Gard, France $\left(44^{\circ} 05^{\prime} 59^{\prime \prime} \mathrm{N} ; 03^{\circ} 58^{\prime} 55^{\prime \prime} \mathrm{E}\right)$.

\subsection{Water physicochemical properties of the sampling sites}

Water physicochemical parameters of the three sites (Table 1) were determined in April 2012, and May 2013 (the latter date corresponds to the collection of water and organisms for Cd toxicity tests) following French standard operating procedures (AFNOR). For both sampling dates, we concluded that the Ard site is a soft water environment (low level of $\mathrm{Ca}^{2+}$ and conductivity) in comparison to the two other sites (Table 1).

The characterization of metallic contamination of the three study sites was made according to the active biomonitoring protocol developed at Irstea (Besse et al., 2013). Following previous studies aiming to document metal effects on invertebrates in natural waters (Luoma et al., 2010; Rainbow et al., 2012), the choice of accumulated concentrations as contamination indicators was made in order to allow a reliable assessment of field exposure of the three populations. This would not have been achieved by measuring dissolved $\mathrm{Cd}$ concentrations in water samples, because this measurement does not integrate the phenomenon of bioavailability, notably the strong effect of water hardness on Cd bioaccumulation process, a parameter which presents marked differences between the three study sites. The active monitoring protocol involved the measurement of metallic concentrations accumulated in transplanted male gammarids from the Bourbre River population after 7-day in situ exposures to the study sites, followed by their comparison with threshold values allowing to evaluate their level of

Table 1

Physicochemical properties of water from the 3 sites in April 2012 and May 2013.

\begin{tabular}{|c|c|c|c|c|c|c|}
\hline & \multicolumn{3}{|c|}{ April 2012} & \multicolumn{3}{|c|}{ May 2013} \\
\hline & \multicolumn{3}{|c|}{$\begin{array}{l}\text { Data used for Cd } \\
\text { speciation modeling }\end{array}$} & \multicolumn{3}{|c|}{ Sampling date } \\
\hline & Bastide & $\begin{array}{l}\text { Tour du } \\
\text { Pin }\end{array}$ & Ardillats & Bastide & $\begin{array}{l}\text { Tour du } \\
\text { Pin }\end{array}$ & Ardillats \\
\hline Conductivity $(\mu \mathrm{S} / \mathrm{cm})$ & 505 & 560 & 105 & 400 & 445 & 95 \\
\hline $\mathrm{NO}_{2}^{-}(\mathrm{mg} / \mathrm{L})$ & $<0.02$ & 0.12 & 0.02 & 0.03 & $<0.02$ & 0.02 \\
\hline $\mathrm{NO}_{3}^{-}(\mathrm{mg} / \mathrm{L})$ & $<1.0$ & 17.0 & 8.2 & $<1.0$ & 15.0 & 9.2 \\
\hline $\mathrm{PO}_{4}^{3-}(\mathrm{mg} / \mathrm{L})$ & $<0.03$ & 0.40 & 0.21 & 0.04 & 0.21 & 0.13 \\
\hline $\mathrm{HCO}_{3}^{-}(\mathrm{mg} / \mathrm{L})$ & 325 & 310 & $<30$ & 250 & 250 & $<30$ \\
\hline $\mathrm{Cl}^{-}(\mathrm{mg} / \mathrm{L})$ & 5 & 16 & 11 & 6 & 10 & 9 \\
\hline $\mathrm{SO}_{4}^{2-}(\mathrm{mg} / \mathrm{L})$ & 13 & 14 & 4 & 13 & 9 & 5 \\
\hline $\mathrm{Mg}^{2+}(\mathrm{mg} / \mathrm{L})$ & 30.8 & 3 & 1.9 & 40.8 & 2.5 & 2.3 \\
\hline $\mathrm{Ca}^{2+}(\mathrm{mg} / \mathrm{L})$ & 66 & 115 & 9 & 23 & 90 & 7 \\
\hline $\mathrm{Na}^{+}(\mathrm{mg} / \mathrm{L})$ & 2.9 & 7 & 8 & 3.4 & 5.1 & 6.6 \\
\hline $\mathrm{K}^{+}(\mathrm{mg} / \mathrm{L})$ & $<1.0$ & 2 & 2 & $<1.0$ & 2.3 & 1 \\
\hline $\mathrm{pH}\left(14^{\circ} \mathrm{c}\right)$ & 8.4 & 8.3 & 8 & 8.5 & 8.5 & 7.7 \\
\hline
\end{tabular}


contamination vs national low level. The complete methodology and full results of the characterization of metallic bioavailable contamination of the Ard and TdP sites are detailed in Vigneron et al. (2015). In addition to these data, a simultaneous bioaccumulation assay performed in April 2012 revealed the low level of bioavailable Cd contamination in Bas site, at $0.32 \pm 0.09 \mu \mathrm{g} / \mathrm{g}$ (dry weight) of accumulated Cd, to be compared to $0.18 \pm 0.04 \mu \mathrm{g} / \mathrm{g}$ DW in Tour du Pin and $1.43 \pm 0.10 \mu \mathrm{g} / \mathrm{g}$ DW in Ard. Hence our experimental design aimed to compare the osmoregulatory reponses to $\mathrm{Cd}$ exposure between gammarids from one Cd chronically exposed population (Ard) and gammarids naïve towards $\mathrm{Cd}$ stress from two other distinct populations (TdP and Bas).

\subsection{Organisms sampling and rearing}

Specimens of G. fossarum were sampled with a net in the three different streams in May 2013. The organisms were transported in plastic vessels to the laboratory, were they were maintained at $12{ }^{\circ} \mathrm{C}$ in aerated non filtered water from their respective sites for 7 days before being used in experiments (water changed every 3 days, photoperiod of $14 \mathrm{~h}$ of light and $10 \mathrm{~h}$ of darkness). Animals were fed ad libitum on alder leaves (Alnus glutinosa). Males in similar intermolt $C$ stage with $10 \mathrm{~mm}$ body size were selected for the study.

\subsection{Cadmium exposure}

These experiments were conducted at the Ecophysiology experimental facility of the University of Montpellier, where the animals had been transported. To avoid any modification of the measured osmoregulatory biomarkers unrelated to $\mathrm{Cd}$ exposure, each population was exposed to $\mathrm{Cd}$ in water sampled from its river of origin. As Cd bioavailability is related to water hardness, total dissolved Cd concentration was adjusted for water from each site to provide a similar $\mathrm{Cd}^{2+}$ exposure $\left(\mathrm{CdCl}_{2}\right.$, Sigma-Aldrich, St Quentin Fallavier, France). For this, we used a speciation modeling approach (Minteq software) based on water physicochemical parameters recorded for the three sites (Table 1 ) to predict the total dissolved Cd concentration that had to be prepared (Table 2). The $9 \mu \mathrm{g} \mathrm{Cd}^{2+} / \mathrm{L}$ experimental concentration was chosen according to our previous results, corresponding to $60 \%$ of the highest Cd level for which no mortality was obtained in our reference population (TdP) for an exposure period of $7 \mathrm{~d}$ (Issartel et al., 2010).

Continuous exposure was performed $(500 \mathrm{~mL}$ tanks were renewed four times a day: flow rate $=1.34 \mathrm{~mL} / \mathrm{min}$ ), using the method described and validated by Felten et al. (2008) and Pellet et al. (2009). Control and contaminated waters from each site, respectively stored in $30 \mathrm{~L}$ containers, were continuously aerated, and distributed to each $500 \mathrm{~mL}$ experimental tank with peristaltic pumps. Four replicates of 30 gammarids were exposed at $12{ }^{\circ} \mathrm{C}$ during $7 \mathrm{~d}$ to the $\mathrm{Cd}$ solutions in $500 \mathrm{~mL}$ tanks. Four replicates of 30 gammarids (time-matched controls, Tc) from each population were also placed in the same conditions but without cadmium during $7 \mathrm{~d}$. During the entire experiment, animals were fed ad libitum on disks of alder leaves. No death occurred during the experiment.

\subsection{Hemolymph sampling and osmolality measurement}

The animals from each site ( $N=120$ for each population) were used for osmolality measurements. Each animal was gently dried between two sheets of filter paper, before one leg was cut using Wecker micro-scissors. The resulting drop of hemolymph was sampled using a hand-made glass micropipette and it was immediately transferred into mineral oil to avoid evaporation. The hemolymph osmolality (HO) was measured on $30 \mathrm{~nL}$ samples with a Kalber-Clifton nano-osmometer (Clifton Technical Physics, Hartford, NY, USA) using a $300 \mathrm{mOsm} / \mathrm{kg}$ internal standard. The rearing water osmolality was measured on a 3300 Advanced Instruments micro-osmometer (Norwood, Massachusetts, USA) using among others the same standard.

In order to highlight potential correlations between the capacity to maintain $\mathrm{HO}$, gill histology and ionic transporter localization and protein expression, specimens exposed (E) to Cd were divided into 2 groups according to their respective HO values (Fig. 2): nonimpacted (NI), with $\mathrm{HO}$ values similar to controls, i.e. ranging from 310 to $280 \mathrm{mOsm} / \mathrm{Kg}$ and impacted (I), with HO values below or equal to $270 \mathrm{mOsm} / \mathrm{Kg}$. In impacted individuals, two sub-groups were separated: slightly impacted (SI) with $\mathrm{HO}$ values ranging from 270 to $250 \mathrm{mOsm} / \mathrm{Kg}$, and highly impacted (HI) with HO ranging from 240 to the lowest measured $\mathrm{HO}$ values (230 mOsm/Kg).

\subsection{Histology}

As described by Issartel et al. (2010), the putative relation between $\mathrm{HO}$ values and histological features of gammarids exposed to cadmium was carefully investigated at the individual level as an important inter-individual variation was observed in this species. Several categories of animals were differentiated according to the value of their hemolymph osmolality (see Results). The histology procedure was realized as described by Issartel et al. (2010). Briefly, following hemolymph sampling, individuals were immediately fixed in a Bouin solution for $24 \mathrm{~h}$. Individuals ( $\mathrm{N}=3-4$ for each category) were then embedded in paraffin, cross-sectioned at $4-\mu \mathrm{m}$ thickness on a Minot Leitz Wetzlar microtome, stained with Masson's trichrome and examined with a light microscope (Leica, Diaplan).

\subsection{Immunocytochemistry}

The preparation of samples for immunocytochemistry was

Table 2

Model predictions of $\mathrm{Cd}$ speciation used to set identical dissolved Cd2+ concentrations ( $8.96 \mu \mathrm{g} / \mathrm{L}$ ) in experimental waters of the 3 sites.

\begin{tabular}{|c|c|c|c|c|c|c|c|c|}
\hline \multicolumn{3}{|l|}{ Tour du Pin } & \multicolumn{3}{|l|}{ Bastide } & \multicolumn{3}{|l|}{ Ardillats } \\
\hline Species name & $\mu \mathrm{g} / \mathrm{L}$ & $\%$ & Species name & $\mu \mathrm{g} / \mathrm{L}$ & $\%$ & Species name & $\mu \mathrm{g} / \mathrm{L}$ & $\%$ \\
\hline $\mathrm{Cd}^{2+}$ & 8.96 & 59.737 & $\mathrm{Cd}^{2+}$ & 8.96 & 53.949 & $\mathrm{Cd}^{2+}$ & 8.96 & 92.999 \\
\hline $\mathrm{CdOH}^{+}$ & 0.05 & 0.331 & $\mathrm{CdOH}^{+}$ & 0.06 & 0.381 & $\mathrm{CdOH}^{+}$ & 0.03 & 0.302 \\
\hline $\mathrm{CdCl}^{+}$ & 0.25 & 1.689 & $\mathrm{Cd}(\mathrm{OH})^{2}(\mathrm{aq})$ & 0.00 & 0.012 & $\mathrm{CdCl}^{+}$ & 0.22 & 2.234 \\
\hline $\mathrm{CdSO}_{4}(\mathrm{aq})$ & 0.10 & 0.656 & $\mathrm{CdCl}^{+}$ & 0.08 & 0.485 & $\mathrm{CdSO}_{4}(\mathrm{aq})$ & 0.05 & 0.536 \\
\hline $\mathrm{CdNO}_{2}^{+}$ & 0.00 & 0.011 & $\mathrm{CdSO}_{4}(\mathrm{aq})$ & 0.10 & 0.579 & $\mathrm{CdNO}_{3}^{+}$ & 0.00 & 0.044 \\
\hline $\mathrm{CdNO}_{3}^{+}$ & 0.01 & 0.047 & $\mathrm{CdHPO}_{4}(\mathrm{aq})$ & 0.00 & 0.012 & $\mathrm{CdHPO}_{4}(\mathrm{aq})$ & 0.05 & 0.471 \\
\hline $\mathrm{CdHPO}_{4}(\mathrm{aq})$ & 0.04 & 0.265 & $\mathrm{CdHCO}_{3}^{+}$ & 0.80 & 4.8 & $\mathrm{CdHCO}_{3}^{+}$ & 0.08 & 0.789 \\
\hline $\mathrm{CdHCO}_{3}^{+}$ & 0.75 & 4.977 & $\mathrm{CdCO}_{3}(\mathrm{aq})$ & 6.32 & 38.032 & $\mathrm{CdCO}_{3}(\mathrm{aq})$ & 0.25 & 2.612 \\
\hline $\mathrm{CdCO}_{3}(\mathrm{aq})$ & 4.68 & 31.177 & $\mathrm{Cd}\left(\mathrm{CO}^{3}\right)_{2}^{2-}$ & 0.29 & 1.747 & - & - & - \\
\hline $\mathrm{Cd}\left(\mathrm{CO}_{3}\right)_{2}^{2-}$ & 0.16 & 1.099 & - & - & - & - & - & - \\
\hline Total dissolved concentration & 15.00 & & Total dissolved concentration & 16.61 & & Total dissolved concentration & 9.63 & \\
\hline
\end{tabular}


performed as described by Boudour-Boucheker et al. (2014). Briefly, after a fixation in Bouin's solution for $24 \mathrm{~h}$, gammarids were embedded in Paraplast (Sigma), 4- $\mu \mathrm{m}$-cross-sectioned on Leitz Wetzlar microtome and collected on poly-L-lysine-coated slides. Slides were then dewaxed and rehydrated through a descending series of ethanol baths.

Immunolocalization of NKA and VHA was performed using a rabbit polyclonal primary antibody (Santa Cruz Biotechnology ${ }^{\circledR}$, Inc., USA) at $200 \mu \mathrm{g} / \mathrm{mL}$ and a Guinea pig polyclonal antibody at $1 /$ 250 dilution in 0,5\% SM-PBS (Wieczorek et al., 1999), respectively. Following washes, the slides were incubated for $1 \mathrm{~h}$ in the dark with a Rhodamine ${ }^{\mathbb{R}}$ donkey secondary anti-rabbit antibody for the NKAmarked slides, and an AlexaFluor ${ }^{\circledR}$ Goat anti-Guniea pig (Invitrogen Molecular Probes, Oregon, USA) for the VHA-marked slides. Control slides were exposed to the same conditions without primary antibody. After being mounted, the slides were observed with a Leitz Diaplan microscope, equipped for fluorescence and with a Leica DC300F camera and FW4000 software (Leica Microsystems, Reuil-Malmaison, France). For co-immunolocalization of NKA and VHA, a few observations were realized using a Leica TCS confocal microscope.

\subsection{Semi-quantification of fluorescence}

All treated pictures were taken using a $40 \times$ objective with an exposure time of $460 \mathrm{~ms}$ in order to ensure the same conditions. The semi-quantification of the fluorescence was performed as described by Burgess et al. (2010) and McCloy et al. (2014) using the corrected total cell fluorescence method using the formula: $\mathrm{CTCF}=$ integrated density - (selected area $\times$ mean fluorescence of background readings), with integrated density representing the sum of the grey values of all the pixels in the selected area relative to the number of pixels. In order to standardize the area of fluorescence measurement, CTCF was assessed in a 600 pixels $(100 \mu \mathrm{m})$ rectangle length $\mathrm{x}$ gill width. Each value represents the mean CTCF
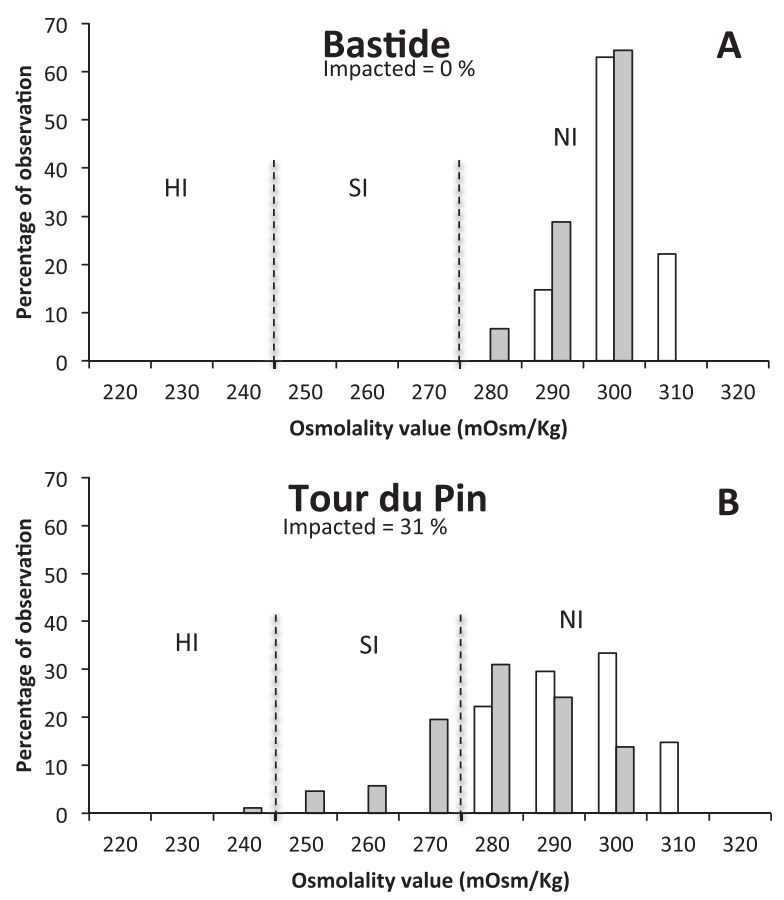

of 7-9 gills from 3 individuals. CTCF measurement was performed using Image J software (Wayne Rasband, US National Institutes of Health, Bethesda, Maryland, USA).

\subsection{Scanning electron microscopy}

Branchial chambers of control individuals from Tour du Pin were fixed in Bouin solution, before being washed in $70^{\circ}$ ethanol and dehydrated in ascendant ethanol series. Samples were then placed in hexamethyldisilazane (HMDS) solution for 30s. After drying at ambient temperature, samples were coated with colloidal platinum under partial airspace. Samples were then observed with a FEI Quanta 200 scanning electron microscope equipped with a Low Field Detector (LFD), using a $15 \mathrm{kV}$ accelerating voltage and a working distance of $10 \mathrm{~nm}$.

\subsection{Statistical analysis}

Differences in hemolymph osmolalities between controls and exposed organisms were assessed performing a one-way ANOVA. When significant differences were found, a Fisher post hoc test was performed. Differences in HO values distributions between control and exposed organisms were analyzed using a KolmogorovSmirnov test. Significance between mean fluorescence (CTCF) of controls and the different categories of exposed animals was analyzed using a Kruskal-Wallis test, followed by a Dunn post hoc test. Statistical analysis was performed using XIStat (Addinsoft, 2010).

\section{Results}

\subsection{Impact of cadmium on hemolymph osmolality}

There was no difference between $\mathrm{HO}$ mean values of controls (C) and of exposed (E) specimens in the 3 populations. However, high

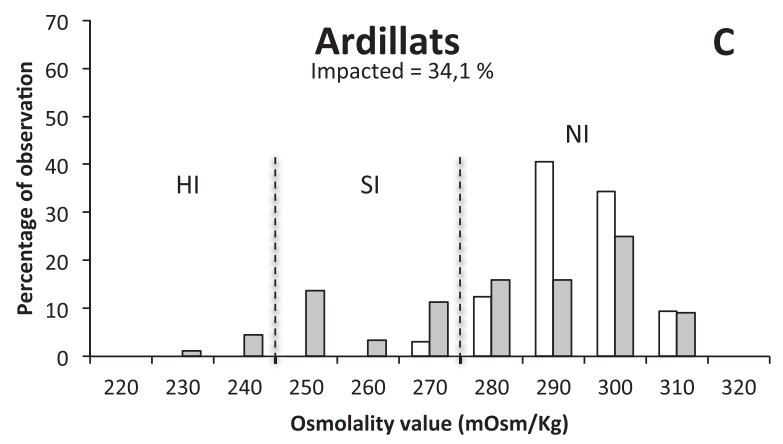

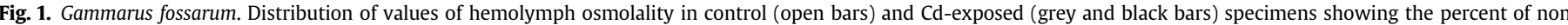

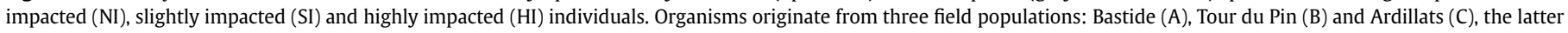
inhabiting an environment characterized by a marked bioavailable $\mathrm{Cd}$ contamination. 
inter-individual variations of HO were observed in Cd-exposed gammarids which are translated by shifts in HO distribution between controls and exposed conditions (Fig. 1). Both Ard (Fig. 1C) and TdP (Fig. 1B) exposed organisms showed significantly different HO distributions compared to controls $(\mathrm{p}=0.001$ and $\mathrm{p}<0.001$, respectively) whereas exposed and controls distributions in Bas specimens (Fig. 1A) were not different $(\mathrm{p}=0,236)$

In the Bas population, all Cd-exposed gammarids showed $\mathrm{HO}$ values in the same range as controls, and were thus all $\mathrm{NI}$ individuals (Fig. 1A). In the TdP population, $31 \%$ of the exposed organisms had HO values below the range of the controls; the

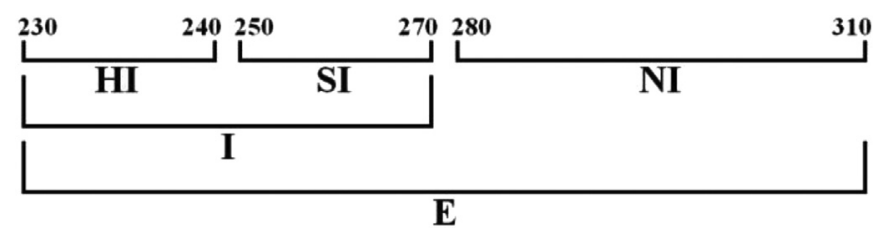

Fig. 2. Gammarus fossarum. Categories of organisms based on their hemolymph osmolality ( $\mathrm{HO}$ in $\mathrm{mOsm} / \mathrm{Kg}$ ) following exposure to $\mathrm{Cd}$. E: Animals exposed to $\mathrm{Cd}$; $\mathrm{NI}$ : Non-impacted; I: Impacted; SI Slightly impacted; HI: Highly impacted. distribution of the HO values showed that among exposed specimens, $30 \%$ of the organisms were SI, and only $1 \%$ were HI (Fig. 1B). In the Ard population, 34\% of the organisms exposed to Cd presented impacted HO values; $28 \%$ of exposed individuals were slightly impacted, and 6\% had highly impacted HO values (Fig. 1C).

\subsection{Effect of cadmium on gill histology, and on localization and} expression of NKA and VHA

\subsubsection{Gill structure}

Gills of $G$. fossarum are typically flattened leaf-shaped single structures (Fig. 3A, B), situated in the pereon region under coxal plates (Fig. 3C). A single layer of epithelial cells limits them on both sides. The abutting basal cell bodies of the opposing epithelial layers delimit the hemolymph spaces together with apical expansions that form an interface beneath the cuticle with other interposed cells (Fig. 4A). At the tips of the gills, large expansions form marginal canals that allow hemolymph to return to the efferent vessel (Fig. 4C). According to the section plane, pillars and marginal canals may appear thinner and smaller, respectively (Fig. 4E). In the Bas population, no modification of the gill histological structure
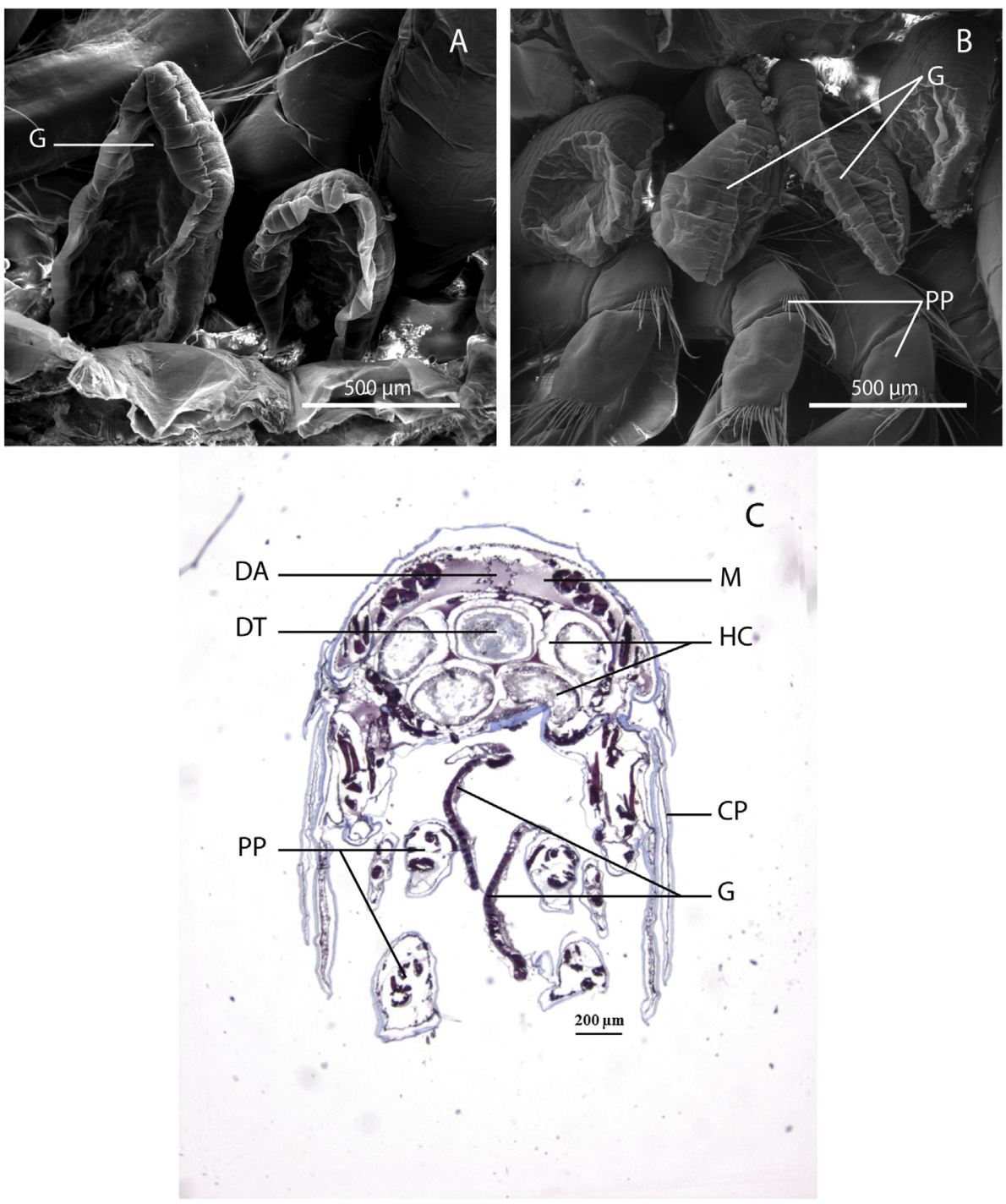

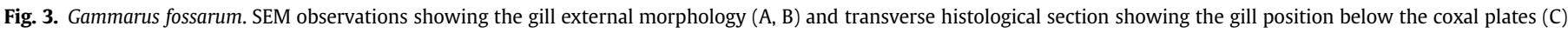
CP: coxal plate; DA: dorsal artery; DT: digestive tract; HC: hepatopancreatic caeca; G: gills; M: muscles; PP: pereopods. 

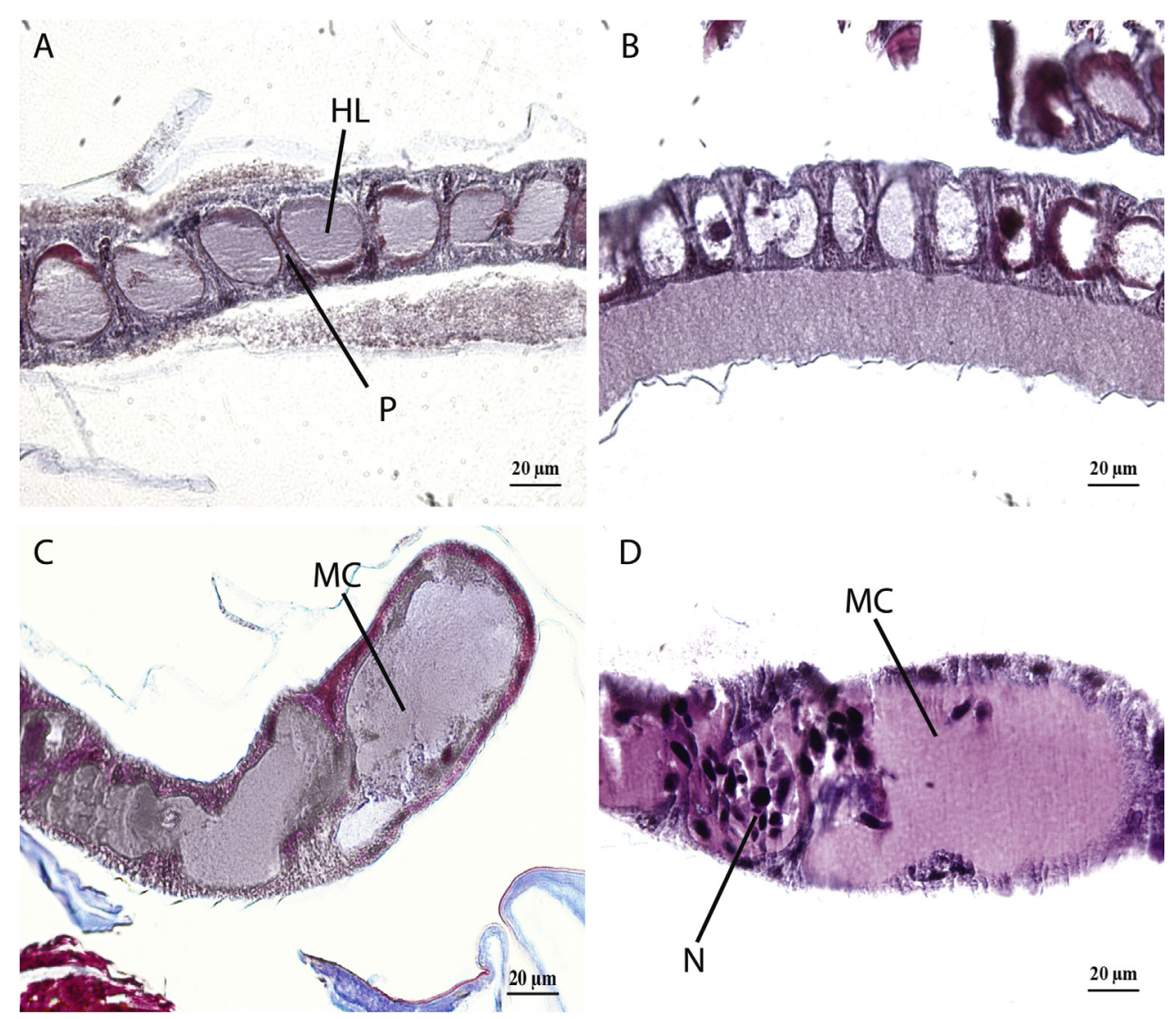

D
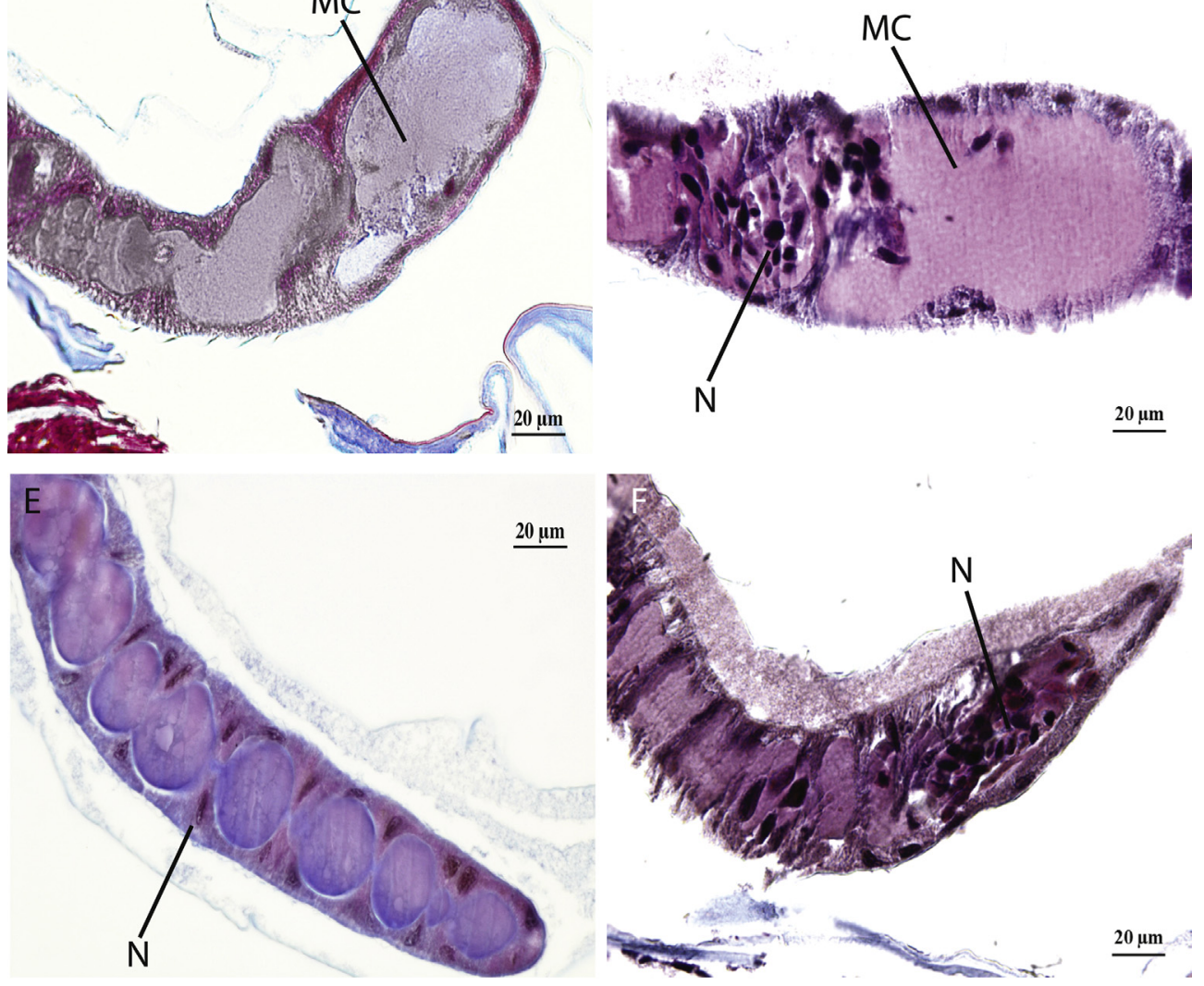

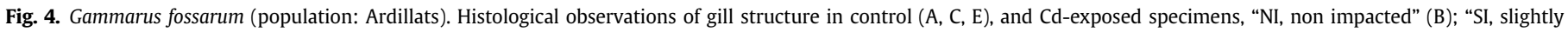
impacted” (D); "HI, highly impacted“ (F). HL: hemolymph lacuna; MC: marginal canal; P: pilaster; N: nucleus. For NI, SI and HI details, see Material and Methods section 5.

was observed compared to controls. However, in both the TdP and Ard populations, histopathological damages were observed in gills after Cd exposure. As they were similar, the following description of the observed histological modifications is thus valid for these two populations. In non-impacted (NI) specimens, no difference with controls was observed (Fig. 4B). In contrast, in slightly and highly impacted (SI and $\mathrm{HI}$ ) individuals (Fig. 4D and F, respectively), a general histological disorder was observed, with cell proliferation (hyperplasia) and increased pigmentation of nuclei.

\subsubsection{Localization of NKA and VHA}

The co-immunolocalization of $\mathrm{Na}^{+} / \mathrm{K}^{+}$-ATPase (red fluorescence) and $\mathrm{V}-\mathrm{H}^{+}$-ATPase (green fluorescence) in a control G. fossarum from the Ard population is illustrated in Fig. 5. NKA immunostaining is observed at the baso-lateral side of the cells and in the deep infoldings of the basal membrane that reach the apical area, whereas VHA is located at the apical and sub-apical pole of cells. The presence of both ionic transporters is revealed by regular and continuous staining along the gill, indicating that all cells of the gill epithelium are involved in ion transport and thus correspond to ionocytes.

\subsubsection{Impact of cadmium on the localization and semi-} quantification of fluorescence of NKA and VHA

The different levels of fluorescence intensity of both ionic transporters observed in each of the four groups of gammarids (C, $\mathrm{NI}, \mathrm{SI}$ and $\mathrm{HI}$ ) from the Ard population are illustrated in Fig. 6. There was no difference of localization and expression in both 


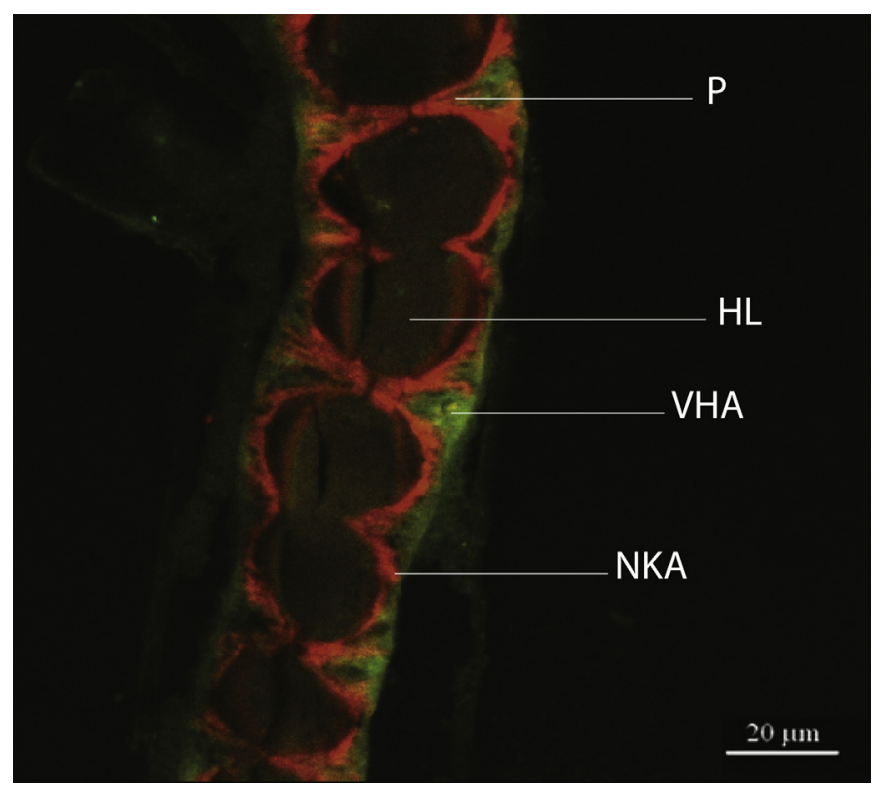

Fig. 5. Gammarus fossarum (population: Ardillats). Co-immunolocalization of $\mathrm{Na}^{+} / \mathrm{K}^{+}$ ATPase (red fluorescence) and V-type $\mathrm{H}^{+}$ATPase (green fluorescence) in a control individual, viewed in confocal microscopy. NKA: $\mathrm{Na}^{+} / \mathrm{K}^{+}$-ATPase, VHA: V-type $\mathrm{H}^{+}$ATPase, P: pillar, HL: hemolymph lacuna. (For interpretation of the references to colour in this figure legend, the reader is referred to the web version of this article.)

VHA and NKA between controls of the three populations. The cellular localization of VHA and NKA in gills was unchanged following $\mathrm{Cd}$ exposure in the three populations. Immunolocalization of NKA and VHA was not visually different between controls (Fig. 6A and B) and NI (Fig. 6C and D), whereas a higher fluorescence level was noticed in HI for both transporters NKA (Fig. 6E) and VHA (Fig. 6F). Intensity of NKA fluorescence returned to control level in HI (Fig. 6G) in contrast to VHA fluorescence (Fig. 6H), which was higher than in controls. The semiquantification of NKA and VHA fluorescence in the 3 populations is illustrated in Fig. 7. In the Bas population, no difference in fluorescence intensity was observed between controls and $\mathrm{NI}$ for both enzymes (Fig. 7A, B). In the TdP population, NKA fluorescence (Fig. 7C) was not affected in NI and SI groups, but it was significantly higher by $150 \%$ in the HI group ( $p<0.05$ ). VHA fluorescence (Fig. 7D) of NI individuals was not different from controls, but it was 5 times significantly higher than in controls in SI and HI organisms ( $\mathrm{p}<0.05$ ). In the Ardillats population, NKA fluorescence (Fig. 7E) was statistically not different from the controls in the NI and HI groups, but it was 3 times higher in SI individuals than in controls ( $\mathrm{p}<0.05$ ). VHA fluorescence (Fig. 7F) was unchanged in NI, but it was 3 times higher and 2.5 times higher in SI and HI organisms, respectively $(\mathrm{p}<0.05)$.

\section{Discussion}

\subsection{Hemolymph osmolality}

Hemolymph osmolality is a highly regulated physiological parameter in osmoregulating crustaceans, particularly in freshwater species. Deviations of the HO from its standard value could have dramatic consequences on the integrity of cells and of their metabolism and ultimately on the survival of organisms (review in Charmantier et al., 2009). In the present work, Cd exposure did not induce an overall homogenous decrease of HO of exposed organisms in any of the tested populations. But, as previously observed in this species (Felten et al., 2008; Issartel et al., 2010), Cd induced high inter-individual variations in HO values, highlighting the existence of different groups of sensitivity among organisms of the same population. Interestingly, the distribution of $\mathrm{HO}$ values and the proportion of impacted organisms following $\mathrm{Cd}$ exposure differed among the three tested populations.

In organisms from Bastide - first Cd-free site -, as Cd exposure did not affect $\mathrm{HO}$, all exposed individuals were thus considered as non-impacted. In contrast, individuals sampled at Tour du Pin second Cd free site -, Cd exposure resulted in 31\% of impacted organisms (i.e. with a significantly lower mean HO than in controls); they mainly included slightly impacted organisms (SI: HO = [270-250] mOsm $/ \mathrm{kg}$ ). In organisms originating from Ardillats, the site with Cd geochemical background (Vigneron et al., 2015), experimental $\mathrm{Cd}$ exposure induced $\mathrm{HO}$ values lower than controls in $34 \%$ of exposed individuals. Among these impacted organisms, a few displayed very low HO values (HI specimens), close to the lethal $\mathrm{HO}$ threshold known in this species $(<210 \mathrm{mOsm} / \mathrm{kg}$ ) (Felten et al., 2008; Issartel et al., 2010). In our previous study, the exposure of G. fossarum from the Tour du Pin population to $\mathrm{Cd}$ for 7 days resulted in high inter-individual variability with $\mathrm{HO}$ values ranging from 280 to $210 \mathrm{mOsm} / \mathrm{kg}$, for a mean $\mathrm{HO}$ of $244 \mathrm{mOsm} / \mathrm{kg}$ (Issartel et al., 2010). The HO profiles reported in the present study are in accordance with these previous results, and they confirm the high inter-individual variability of responses to $\mathrm{Cd}$ in this population. As variability due to sex, size/age and molt cycle was avoided by selecting only males of a determined size range and intermolt stage in both studies, the observed heterogeneity of $\mathrm{HO}$ values in responses to contamination may be due to a high genetic and/or phenotypic variability within and between populations (Vigneron et al., 2015, 2016).

These results show that there is no obvious relationship between the respective levels of contamination of the different natural populations and the intra- and inter-populationnal sensitivities to $\mathrm{Cd}$, as both reference populations TdP and Bas were differently affected by an experimental $\mathrm{Cd}$ exposure, whereas TdP and the naturally Cd-exposed population Ard show similar HO ranges profiles.

\subsection{Gill histology}

In order to study the impact of cadmium in G. fossarum tissues and to decipher the cellular basis of $\mathrm{HO}$ alteration among the three populations, the structure of gills from non-impacted, slightly impacted and highly impacted organisms was then investigated. Gills of $G$. fossarum are characterized by a typically flattened shape, and are constituted by two single layer epithelia separated by pillar cells, delimiting hemolymphatic space in which hemolymph flows. In individuals from Bas, Cd exposure did not induce HO disturbance, and interestingly, no alteration of the gill structure was observed in this population. In contrast, histological observations of exposed organisms from the TdP and Ard populations revealed that Cd similarly induced histopathological damages in gills of individuals in which HO levels decreased, but not in NI. In SI and HI gills of specimens from both populations, hyperplasia (i.e. abnormal cell proliferation) and increased nuclear pigmentation were noticed at the tips of the gills. These typical histopathological effects of Cd confirmed the observations previously conducted on gills of G. fossarum (Issartel et al., 2010) and in other crustaceans such as the shrimps Penaeus japonicus (Soegianto et al., 1999) and P. duorarum (Couch, 1977), the crayfish Procambarus clarkii (Torreblanca et al., 1989) or the freshwater crab Sinopotamon henanse (Wang et al., 2013). Cadmium is thought to enter aquatic organisms from the water through gills via calcium channels of the apical plasma membrane of cells (Verbost et al., 1989; Wang et al. 2013). In addition to the consequent disturbance in $\mathrm{Ca}^{2+}$ 

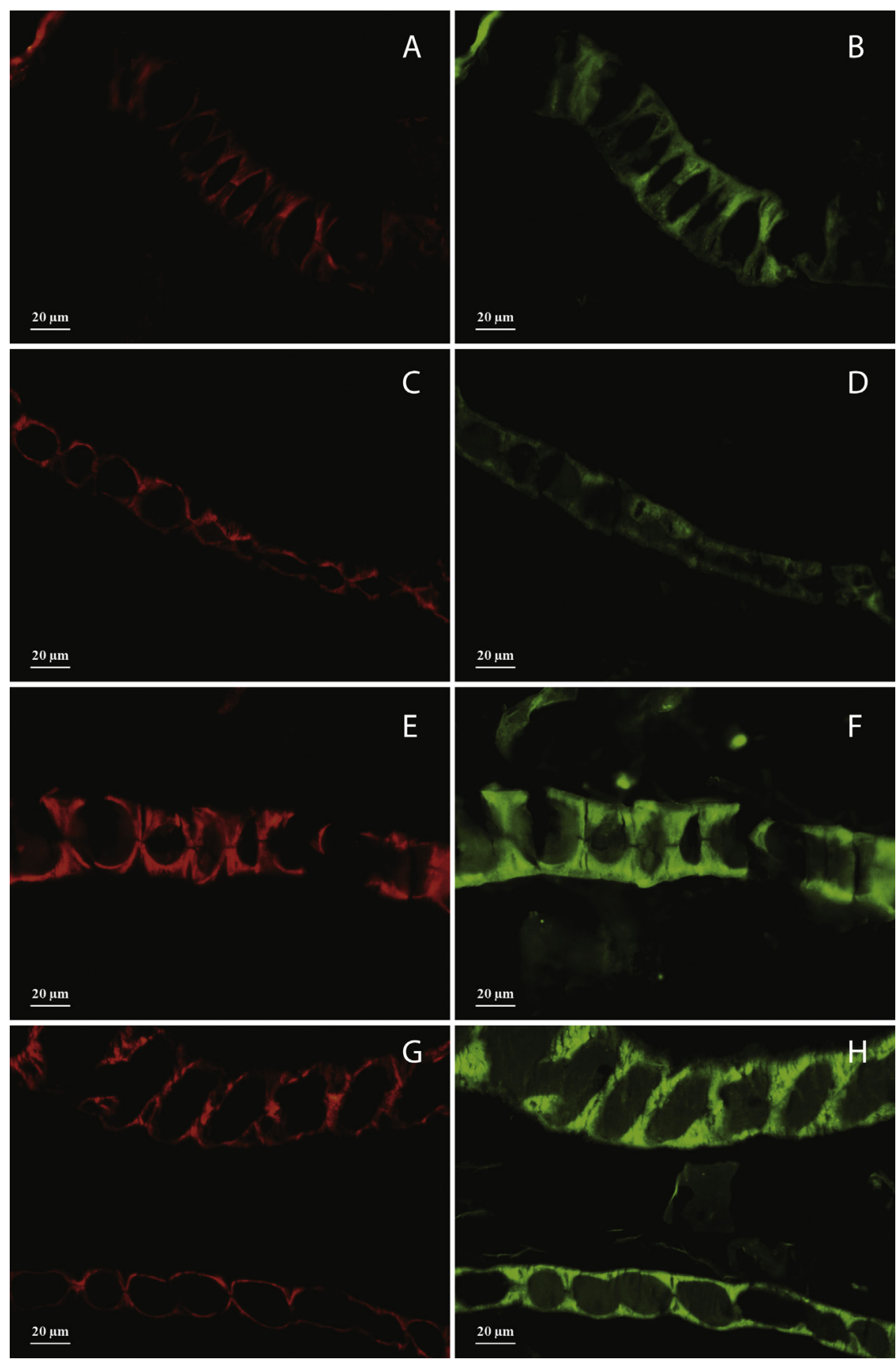

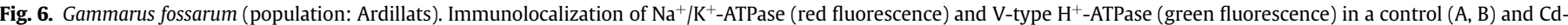

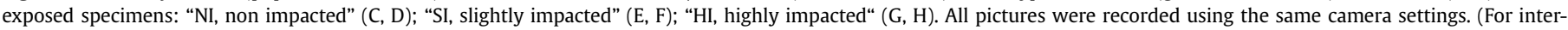
pretation of the references to colour in this figure legend, the reader is referred to the web version of this article.)

homeostasis, once $\mathrm{Cd}$ is inside the cell, the metal is also known to induce a massive production of reactive oxygen species (ROS) by altering mitochondrial properties and antioxidant system (Bertin and Averbeck, 2006), possibly triggering cell death mechanisms such as apoptosis and necrosis. For instance, in the freshwater crab Sinopotamon henanse exposed to $14.5 \mathrm{mgCd} / \mathrm{L}$ for $24 \mathrm{~h}$, a concomitant increase of the $\mathrm{ROS}_{2} \mathrm{O}_{2}$ and malondialdehyde (a sub-product of lipid peroxidation by ROS) was measured in the gills, followed by the appearance of apoptotic and necrotic cells after a $48 \mathrm{~h}$ and $72 \mathrm{~h}$ exposure, respectively (Wang et al., 2013). In our experiment, gammarids were exposed to a much lower Cd dose but for a longer experimental period, and comparable phenomena may have occurred in gill cells, resulting in the observed histopathological alterations. Metals and particularly Cd are also known to induce alterations of the cytoskeletal organization (Li et al., 1993; Silvestre et al., 2006). In G. fossarum gills, a disruption of the microtubules of gill cells by Cd could affect the cell structure and hemolymph flow within the gill, as it was suggested for copper in Carcinus maenas (Lawson et al., 1995). In this study, the observed tissular disorganization of gill epithelium coincides with lower HO levels of SI and 
(A)

Bastide
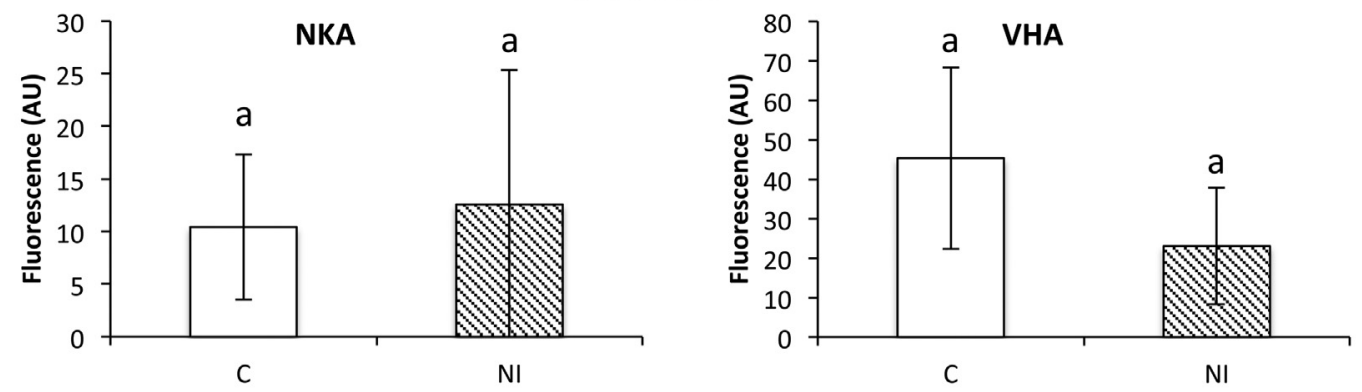

(C)

Tour du Pin

(D)
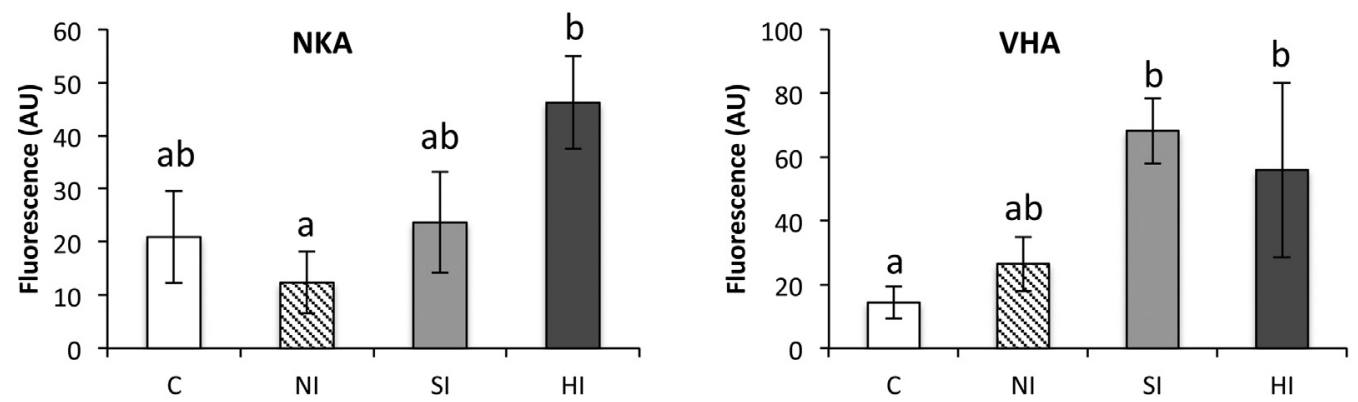

(E)

Ardillats

$(\mathrm{F})$
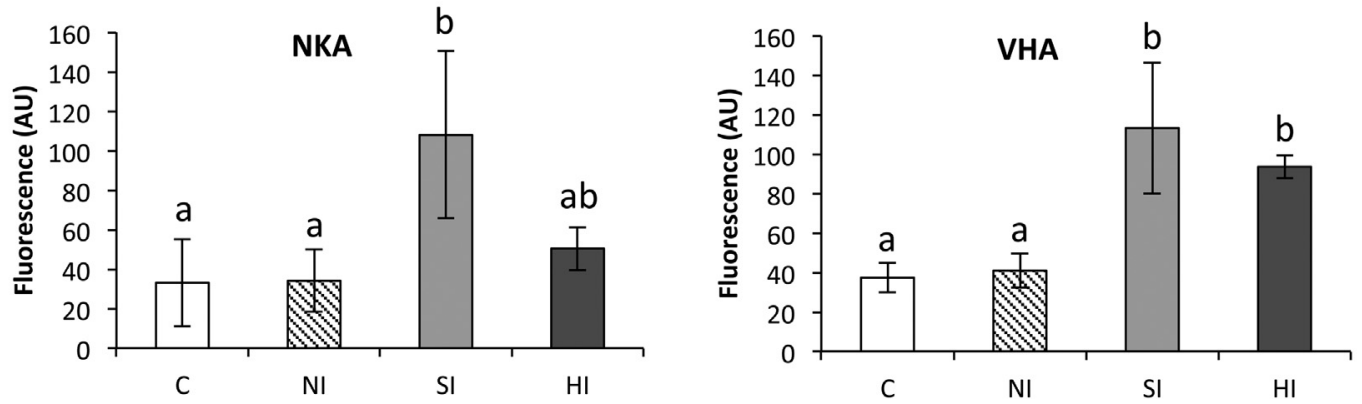

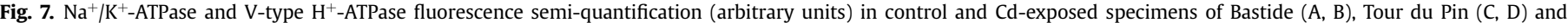

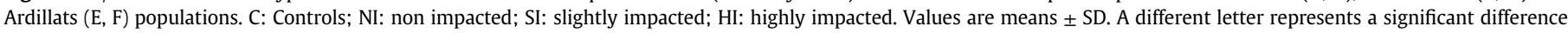
$(\mathrm{P}<0.05)$.

$\mathrm{HI}$ in both impacted populations. The altered ability to osmoregulate in these groups may originate from cell death and cytoskeletal disruption resulting in an increased ion loss in freshwater, and ultimately in a decrease of HO. However, hyper-osmoregulators as G. fossarum actively uptake ions from their environment via specific ionic transporters located in the epithelial cells of gills, which we studied using immunolocalization and semiquantification of NKA and VHA.

\subsection{Immunolocalization and semi-quantification of NKA and VHA}

Co-immunolocalization of NKA and VHA in G. fossarum gills confirmed their respective positions in crustacean ionocytes, with baso-lateral NKA and apical or sub-apical VHA. Similar localizations of VHA have been reported in other freshwater crustaceans e.g. the crabs Uca formosensis (Tsai and Lin, 2007) and Dilocarcinus pagei (Weihrauch et al., 2004), the shrimp Macrobrachium amazonicum (Boudour-Boucheker et al., 2014), and the copepod Eurytemora affinis (Johnson et al., 2014). The respective localizations of NKA and
VHA reinforce the hypothesis of their synergic action to compensate ionic efflux (Beyenbach, 2001; Weihrauch et al., 2001, 2004; Charmantier et al., 2009; McNamara and Faria, 2012). In ionocytes of freshwater hyper-osmoregulators, basal secretion of $\mathrm{Na}^{+}$ by NKA from the cytoplasm to the hemolymph induces an apical uptake of $\mathrm{Na}^{+}$from the external medium, which is facilitated by the increased electronegativity on the cytosolic side of the apical membrane resulting from apical $\mathrm{H}^{+}$secretion by VHA. The resulting increased electronegativity of the inner side of the apical membrane facilitates $\mathrm{Na}^{+}$entry into the cell trough apical sodium channels or still unknown $\mathrm{Na} / \mathrm{H}$ exchangers, feeding the basal NKA (reviews in Charmantier et al., 2009; McNamara and Faria, 2012).

In accordance with physiological observations, Cd exposure resulted in drastically different fluorescence patterns of ion transporters between the Bas (pristine) population and the TdP and especially the Ard (chronically Cd-exposed) populations. In the Bas population, in which neither impacted HO nor histopathology were observed, no difference in VHA and NKA protein abundance was noticed in non impacted (NI) individuals 
compared to controls. In contrast, in the TdP population, both NKA and VHA protein abundance showed important variations in impacted specimens. NKA protein expression was higher in highly impacted specimens, and VHA was strongly over-expressed in both slightly impacted (SI) and highly impacted $\mathrm{HI}$ ) groups. In the Ard population, exposed individuals also showed an increased presence of VHA in SI and HI; NKA increased only in SI but not in the most severely impacted organisms HI. In summary, NKA and VHA protein abundance in gills varied in the slightly and highly impacted organisms from both responsive populations TdP and Ard. The observed increased abundance of these two key enzymes may represent a mechanism aiming at increasing the efficiency of ion uptake to compensate the higher ion loss resulting from $\mathrm{Cd}-$ induced disruption of the gill structure. Cd and other metals are known to influence NKA enzymatic activity in crustaceans (review in Lignot et al., 2000). For example, a $6.5 \mu \mathrm{g} \mathrm{Cd} / \mathrm{L}$ exposure for $10 \mathrm{~d}$ induced a 50\% decrease in NKA activity in the amphipod Hyalella curvispina (Giusto and Ferrari, 2014). By contrast, Felten et al. (2008) measured a significant increase of the gill NKA activity in Gammarus exposed to $15 \mu \mathrm{g} \mathrm{Cd} / \mathrm{L}$ for $7 \mathrm{~d}$. In aquatic organisms, NKA enzymatic activity is controlled by expression level and phosphorylation (Péqueux, 1995; Lucu and Flik, 1999; Towle et al., 2001; Lovett et al., 2006). Cd is known to bind to proteins and to alter their conformation and activity (Bertin and Averbeck, 2006). Organisms may respond to altered NKA conformation by $\mathrm{Cd}$ that is leading to a decrease of its activity, by increasing the expression of NKA in gills, or by increasing the pool of active - phosphorylated enzymes to maintain hemolymph osmolality. In this study, the higher abundance of NKA and VHA measured in Cd-impacted organisms is in accordance with an adaptive increase of enzyme concentration, and it is in agreement with the higher NKA activity previously measured in Cd-exposed gammarids (Felten et al., 2008). In addition to the increase in NKA measured in HI (from TdP individuals) and SI (from Ard individuals), the present study showed that VHA was over-expressed in slightly and highly impacted individuals from both populations. These results confirm that NKA and VHA cooperate in ion uptake and that VHA plays a crucial role in the maintenance of ionic homeostasis in freshwater hyperosmoregulators.

\section{Conclusion}

All 3 tested populations showed similar physiological profiles under control conditions: no influence of a chronic Cd exposure in its natural habitat was found in Ard compared to reference (metalfree) populations Bas and TdP. Organisms from Ard may cope with high Cd level by higher "basal" expressions of metallothioneins, and/or antioxidant enzymes. However, after Cd exposure in laboratory conditions, the response profiles of exposed organisms differed between the TdP and Bas reference populations and between Bas and the Cd-exposed population Ard. The first reference population living in the pristine $\mathrm{Cd}$-free site (Bastide) was not impacted by $\mathrm{Cd}$ exposure in laboratory conditions, whereas organisms from the other reference $\mathrm{Cd}$ free site (Tour du Pin) and from the river contaminated by $\mathrm{Cd}$ geochemical background (Ardillats) showed high inter-individual variations in HO values both in control and Cd conditions, with slightly and highly Cdimpacted organisms. In gills of the impacted organisms of both affected populations, deep histopathological alterations and a protein over-expression of NKA and VHA were observed, while non-impacted animals showed profiles comparable to controls. These different patterns of responses between populations revealed no obvious adaptive phenomena in relation to the $\mathrm{Cd}$ levels of their respective biotopes. However, the strong impact of Cd exposure in Ard organisms may reflect the saturation of their defense mechanisms that were already challenged by the chronic $\mathrm{Cd}$ level in their natural habitat. Furthermore, Ard individuals evolve in a river showing a slightly lower conductivity compared to the other sites, that may affect their capacity to respond to environmental stressors, as observed in a freshwater population of the amphipod Gammarus lacustris compared to saline counterparts (Vereshchagina et al., 2016).

As a result, the difference of profiles following $\mathrm{Cd}$ exposure could be explained by different levels of fitness and differences in energy allocation profiles between populations in response to the features of their natural environment.

The present study confirmed that osmoregulation represents a relevant biomarker to assess crustacean physiological status. By depicting for the first time in amphipods the co-localization of the two most important ionic transporters in gills, we gave new information regarding the impact of metal contamination on osmoregulation in freshwater crustaceans. Furthermore, by measuring the inter-individual responses, the impact of toxicological phenomena was highlighted whereas it would have been hidden by a global conventional approach. Finally, we have demonstrated that a common exposure to a contaminant in a same species could lead to drastically different responses according to the population tested. Consequently, studying the inter-populational variation of vulnerability to chemical stressors in relation to life history or to preexposure of populations in the field is mandatory in order to yield robust hazard assessment of environmental contaminations.

\section{Acknowledgements}

Funding was provided by ANR CESA ( $\mathrm{n}^{\circ} 021$ 04), GAMMA, 2012-2015.

We thank Prof. Helmut Wieczorek and Dr. Markus Huss, University of Osnabrück, Germany for kindly providing the VHA antibody. We thank Dr. G. Rivera-Ingraham for her help in confocal microscopy, E. Grousset and E. Bidet for their technical supports in histology. We are indebted to Dr. J. Lebrun for speciation modeling. The authors also thank G. Jubeaux and A. François for their assistance in the field and laboratory experiments.

\section{References}

Bertin, G., Averbeck, D., 2006. Cadmium: cellular effects, modifications of biomolecules, modulation of DNA repair and genotoxic consequences (a review). Biochimie 88, 1549-1559.

Besse, J.-P., Coquery, M., Lopes, C., Chaumot, A., Budzinski, H., Labadie, P., Geffard, O., 2013. Caged Gammarus fossarum (Crustacea) as a robust tool for the characterization of bioavailable contamination levels in continental waters: towards the determination of threshold values. Water Res. 47, 650-660.

Beyenbach, K.W., 2001. Energizing epithelial transport with the vacuolar $\mathrm{H}^{+}$ATPase. Physiology 16, 145.

Boudour-Boucheker, N., Boulo, V., Charmantier-Daures, M., Grousset, E., Anger, K., Charmantier, G., Lorin-Nebel, C., 2014. Differential distribution of V-type $\mathrm{H}^{+}$ATPase and $\mathrm{Na}^{+} / \mathrm{K}^{+}$-ATPase in the branchial chamber of the palaemonid shrimp Macrobrachium amazonicum. Cell Tissue Res. 357, 195-206.

Burgess, A., Vigneron, S., Brioudes, E., Labbé, J.-C., Lorca, T., Castro, A., 2010. Loss of human Greatwall results in G2 arrest and multiple mitotic defects due to deregulation of the cyclin B-Cdc2/PP2A balance. Proc. Natl. Acad. Sci. U. S. A. 107, 12564-12569.

Charmantier, G., Charmantier-Daures, M., Towle, D.W., 2009. Osmotic and ionic regulation in aquatic arthropods. In: Evans, D.H. (Ed.), Osmotic and Ionic Regulation: Cells and Animals. Taylor and Francis, London, pp. 165-208.

Couch, J.A., 1977. Ultrastructural study of lesions in gills of a marine shrimp exposed to cadmium. J. Invertebr. Pathol. 29, 267-288.

Felten, V., Charmantier, G., Mons, R., Geffard, A., Rousselle, P., Coquery, M., Garric, J., Geffard, O., 2008. Physiological and behavioural responses of Gammarus pulex (Crustacea: Amphipoda) exposed to cadmium. Aquat. Toxicol. 86, 413-425.

Giusto, A., Ferrari, L., 2014. Biochemical responses of ecological importance in males of the austral South America amphipod Hyalella curvispina shoemaker, 1942 exposed to waterborne cadmium and copper. Ecotoxicol. Environ. Saf. 100, 193-200.

Issartel, J., Boulo, V., Wallon, S., Geffard, O., Charmantier, G., 2010. Cellular and molecular osmoregulatory responses to cadmium exposure in Gammarus 
fossarum (Crustacea, Amphipoda). Chemosphere 81, 701-710.

Johnson, K.E., Perreau, L., Charmantier, G., Charmantier-Daures, M., Lee, C.E., 2014 Without gills: localization of osmoregulatory function in the copepod Eurytemora affinis. Physiol. Biochem. Zool. 87, 310-324.

Karaman, G.S., Pinkster, S., 1977. Freshwater Gammarus species from Europe, North Africa and adjacent regions of Asia (Crustacea Amphipoda). Part I. Gammarus pulex-group and related species. Bijdr. Tot Dierkd. 47, 1-97.

Lawrence, A., Poulter, C., 1998. Development of a sub-lethal pollution bioassay using the estuarine amphipod Gammarus duebeni. Water Res. 32, 569-578.

Lawson, S.L., Jones, M.B., Moate, R.M., 1995. Effect of copper on the ultrastructure of the gill epithelium of Carcinus maenas (Decapoda: Brachyura). Mar. Pollut. Bull. 31, 63-72.

Li, W.D., Zhao, Y., Chou, I.N., 1993. Alterations in cytoskeletal protein sulfhydryls and cellular glutathione in cultured cells exposed to cadmium and nickel ions. Toxicology 77, 65-79.

Lignot, J.H., Spanings-Pierrot, C., Charmantier, G., 2000. Osmoregulatory capacity as a tool in monitoring the physiological condition and the effect of stress in crustaceans. Aquaculture 191, 209-245.

Lovett, D.L., Verzi, M.P., Burgents, J.E., Tanner, C.A., Glomski, K., Lee, J.J., Towle, D.W., 2006. Expression profiles of $\mathrm{Na}^{+}, \mathrm{K}^{+}$-ATPase during acute and chronic hypoosmotic stress in the blue crab Callinectes sapidus. Biol. Bull. 211, 58-65.

Lucu, Č., Flik, G., 1999. $\mathrm{Na}^{+} / \mathrm{K}^{+}$-ATPase and $\mathrm{Na}^{+} / \mathrm{Ca}^{2+}$ exchange activities in gills of hyperregulating Carcinus maenas. Am. J. Physiol. Regul. Integr. Comp. Physiol. 276, R490.

Luoma, S.N., Cain, D.J., Rainbow, P.S., 2010. Calibrating biomonitors to ecological disturbance: a new technique for explaining metal effects in natural waters. Integr. Environ. Assess. Manage. 6, 199-209.

Maltby, L., Clayton, S.A., Wood, R.M., McLoughlin, N., 2002. Evaluation of the Gammarus pulex in situ feeding assay as a biomonitor of water quality: robustness, responsiveness, and relevance. Environ. Toxicol. Chem. 21, 361-368.

McCloy, R.A., Rogers, S., Caldon, C.E., Lorca, T., Castro, A., Burgess, A., 2014. Partial inhibition of Cdk1 in G2 phase overrides the SAC and decouples mitotic events. Cell Cycle 13, 1400-1412.

McNamara, J.C., Faria, S.C., 2012. Evolution of osmoregulatory patterns and gill ion transport mechanisms in the decapod Crustacea: a review. J. Comp. Physiol. B Biochem. Syst. Environ. Physiol. 182, 997-1014.

Mills, C.L., Shukla, D.H., Compton, G.J., 2006. Development of a new low cost high sensitivity system for behavioural ecotoxicity testing. Aquat. Toxicol. 77, 197-201.

Morin, S., Duong, T.T., Dabrin, A., Coynel, A., Herlory, O., Baudrimont, M., Delmas, F., Durrieu, G., Schäfer, J., Winterton, P., Blanc, G., Coste, M., 2008. Long-term survey of heavy-metal pollution, biofilm contamination and diatom community structure in the Riou Mort watershed, South-West France. Environ. Pollut. 151, $532-542$.

Pellet, B., Geffard, O., Lacour, C., Kermoal, T., Gourlay-Francé, C., TusseauVuillemin, M.-H., 2009. A model predicting waterborne cadmium bioaccumulation in Gammarus pulex: the effects of dissolved organic ligands, calcium, and temperature. Environ. Toxicol. Chem. 28, 2434-2442.

Péqueux, A., 1995. Osmotic regulation in Crustaceans. J. Crustac. Biol. 15, 1-60.

Rainbow, P.S., Hildrew, A.G. Smith, B.D., Geatches, T., Luoma, S.N., 2012. Caddisflies as biomonitors identifying thresholds of toxic metal bioavailability that affect the stream benthos. Environ. Pollut. 166, 196-207.

Silvestre, F., Dierick, J.-F., Dumont, V., Dieu, M., Raes, M., Devos, P., 2006. Differentia protein expression profiles in anterior gills of Eriocheir sinensis during acclimation to cadmium. Aquat. Toxicol. 76, 46-58.

Soegianto, A., Charmantier-Daures, M., Trilles, J.-P., Charmantier, G., 1999. Impact of cadmium on the structure of gills and epipodites of the shrimp Penaeus japonicus (Crustacea: Decapoda). Aquat. Living Resour. 12, 57-70.

Torreblanca, A., Del Ramo, J., Arnau, J.A., Diaz-Mayans, J., 1989. Cadmium, mercury, and lead effects on gill tissue of freshwater crayfish Procambarus clarkii (girard) Biol. Trace Elem. Res. 21, 343.

Towle, D.W., Paulsen, R.S., Weihrauch, D., Kordylewski, M., Salvador, C., Lignot, J.-H. Spanings-Pierrot, C., 2001. $\mathrm{Na}^{+} / \mathrm{K}^{+}$-ATPase in gills of the blue crab Callinectes sapidus: cDNA sequencing and salinity-related expression of $\alpha$-subunit mRNA and protein. J. Exp. Biol. 204, 4005.

Tsai, J.-R., Lin, H.-C., 2007. V-type $\mathrm{H}^{+}$-ATPase and $\mathrm{Na}^{+}$-ATPase in the gills of 13 euryhaline crabs during salinity acclimation. J. Exp. Biol. 210, 620.

Verbost, P.M., Van Rooij, J., Flik, G., Lock, R.A.C., Bonga, S.E.W., 1989. The movement of cadmium through freshwater trout branchial epithelium and its interference with calcium transport. J. Exp. Biol. 145, 185-197.

Vereshchagina, K.P., Lubyaga, Y.A., Shatilina, Z., Bedulina, D., Gurkov, A., AxenovGribanov, D.V., Baduev, B., Kondrateva, E.S., Gubanov, M., Zadereev, E. Sokolova, I., Timofeyev, M., 2016. Salinity modulates thermotolerance, energy metabolism and stress response in amphipods Gammarus lacustris. Peer] 4, e2657.

Vigneron, A., Geffard, O., Coquery, M., François, A., Quéau, H., Chaumot, A., 2015 Evolution of cadmium tolerance and associated costs in a Gammarus fossarum population inhabiting a low-level contaminated stream. Ecotoxicology 24 1239-1249.

Vigneron, A., Geffard, O., Quéau, H., Chaumot, A., 2016. Mothers and not genes determine inherited differences in cadmium sensitivities within unexposed populations of the freshwater crustacean Gammarus fossarum. Evol. Appl. 9 355-366.

Wallace, W.G., Estephan, A., 2004. Differential susceptibility of horizontal and vertical swimming activity to cadmium exposure in a gammaridean amphipod (Gammarus lawrencianus). Aquat. Toxicol. 69, 289-297.

Wang, J., Zhang, P. Shen, O, Wang O, Liu, D., Li, J., Wang L, 2013. The effects of cadmium exposure on the oxidative state and cell death in the gill of freshwater crab Sinopotamon henanense. PLoS One 8, e64020.

Weihrauch, D., McNamara, J.C., Towle, D.W., Onken, H., 2004. Ion-motive ATPases and active, transbranchial $\mathrm{NaCl}$ uptake in the red freshwater crab, Dilocarcinus pagei (Decapoda, Trichodactylidae). J. Exp. Biol. 207, 4623.

Weihrauch, D., Ziegler, A., Siebers, D., Towle, D.W., 2001. Molecular characterization of V-type $\mathrm{H}(+)$-ATPase (B-subunit) in gills of euryhaline crabs and its physiological role in osmoregulatory ion uptake. J. Exp. Biol. 204, 25.

Wieczorek, H., Brown, D., Grinstein, S., Ehrenfeld, J., Harvey, W.R., 1999. Anima plasma membrane energization by proton-motive V-ATPases. Bioessays 21 637-648.

Wu, J.-P., Chen, H.-C., 2005. Effects of cadmium and zinc on the growth, food consumption, and nutritional conditions of the white shrimp, Litopenaeus vannamei (boone). Bull. Environ. Contam. Toxicol. 74, 234-241. 